DOI: https://doi.org/10.24127/ajpm.v9i2.2764

\title{
PENGARUH STRATEGI PEMBELAJARAN EVERYONE IS A TEACHER HERE TERHADAP HASIL BELAJAR MATEMATIKA
}

\author{
Halidin ${ }^{1}$ \\ ${ }^{1}$ Pendidikan Matematika, Universitas Sembilanbelas November Kolaka, Indonesia \\ E-mail: halidinidin@yahoo.co.id ${ }^{1)}$
}

Received 19 April 2020; Received in revised form 17 June 2020; Accepted 28 June 2020

\begin{abstract}
Abstrak
Penelitian ini berbentuk Quasi Experimental dengan rancangan Nonequivalent Control Group Design dengan tujuan untuk mengetahui pengaruh positif dan signifikan strategi pembelajaran Everyone is a Teacher Here terhadap hasil belajar matematika siswa kelas XI MIA SMA Negeri 1 Latambaga. Populasi dalam penelitian ini adalah semua siswa kelas XI MIA SMA Negeri 1 Latambaga Tahun ajaran 2019/2020. Pengambilan sampel dilakukan dengan teknik purposive sampling. Teknik pengumpulan data dilakukan dengan teknik tes menggunakan soal pree-test dan post-test. dimana pengujian hipotesis terhadap peningkatan hasil belajar dengan menggunakan Independent T-test (Polled Varians) $t_{\text {hitung }}$ $(5,360)>t_{\text {tabel }}(1,992)$, dengan kata lain nilai rata-rata hasil belajar kelompok siswa yang diajar menggunakan strategi pembelajaran Everyone is a Teacher Here lebih tinggi dari pada nilai rata-rata hasil belajar siswa yang diajar menggunakan pembelajaran konvensional. Dari hasil penelitian dapat disimpulkan bahwa terdapat pengaruh positif dan signifikan terhadap hasil belajar matematika siswa kelas XI MIA SMA Negeri 1 Latambaga. Kemudian untuk mengukur seberapa besar pengaruh yang ditimbulkan akibat penggunaan strategi pembelajaran Everyone is a Teacher Here maka dilakukan perhitungan effect size menggunakan rumus Cohens $(d)$ dimana hasil perhitungan diperoleh effect size sebesar 1,23 yang termasuk dalam kategori efek sangat besar.
\end{abstract}

Kata kunci: Hasil belajar; strategi; everyone teacher here $(E T H)$.

\begin{abstract}
This research is form of Quasi Experimental, Nonequivalent Control Group Design with the aim to find out positive and significant effect of learning strategies Everyone is a Teacher Here on mathematics learning outcomes of students of grade XI MIA of SMA Negeri 1 Latambaga. The population in this study were all students of class XI MIA SMA Negeri 1 Latambaga 2019/2020. Sampling was done by purposive sampling technique. The technique of data collection is done by using test pree-test and post-test questions. where testing hypotheses to increase learning outcomes using Independent T-test (Polled Variance) tcount (5,360)> ttable (1,992), in other words the average value of the learning outcomes of groups of students taught using the learning strategy Everyone is a Teacher Here is higher than the average value of student learning outcomes taught using conventional learning. From the results of this study it can be concluded that there is a positive and significant influence on mathematics learning outcomes of students of class XI MIA SMA Negeri 1 Latambaga. Then to measure how much influence is caused due to the use of Everyone is a Teacher Here learning strategy, the effect size calculation is done using the Cohens formula (d) where the calculation results obtained an effect size of 1.23 which is included in the category of very large effects.
\end{abstract}

Keywords: Everyone teacher here (ETH); learning outcomes; strategy.

\section{PENDAHULUAN}

Pembelajaran merupakan suatu usaha pendidik untuk membantu siswa dalam kegiatan belajar mengajar. Dalam proses pembelajaran diperlukan suatu strategi pembelajaran yang dapat meningkatkan kualitas pembelajaran.
Hamdani (2011); Tambunan (2018) Menyatakan bahwa strategi adalah kegiatan upaya, desain, pendekatan, dan serangkaian langkah yang diambil oleh guru untuk mencapai tujuan pendidikan.

Dewasa ini dibutuhkan suatu strategi belajar yang dapat menghidup- 
kan kelas secara maksimal. Kelas yang hidup diharapkan dapat mengimbangi perubahan yang terjadi di luar sekolah yang demikian cepat. Dengan konsep itu, hasil pembelajaran diharapkan lebih bermakna bagi siswa. Proses pembelajaran berlangsung alamiah dalam bentuk kegiatan siswa bekerja dan mengalami, bukan transfer pengetahuan dari guru ke siswa. Siswa perlu mengerti apa makna belajar, apa manfaatnya dan cara mencapainya. Mereka harus menyadari bahwa yang mereka pelajari berguna bagi hidupnya (Sucidamayanti, 2017). Penggunaan strategi yang tepat akan meningkatkan proses pembelajaran. Dalam pembelajaran aktif terdapat banyak tipe yang dapat digunakan dalam proses belajar mengajar di kelas, salah satunya yaitu strategi pembelajaran Everyone is a Teacher here (setiap orang adalah guru disini). Strategi pembelajaran Everyone is a teacher here merupakan bagian dari strategi pembelajaran aktif yang dalam pelaksanaannya menuntut partisipasi seluruh kelas dan pertanggungjawaban individu dengan memberi kesempatan bagi setiap siswa untuk bertindak sebagai guru bagi siswa yang lain. Strategi pembelajaran Everyone is a Teacher Here ini juga dapat digunakan untuk memastikan keterlibatan seluruh siswa dalam proses pembelajaran.

Beberapa penelitian yang berkaitan dengan strategi pembelajaran aktif tipe Everyone is a Teacher Here (ETH) menunjukkan hasil yang positif terhadap hasil pembelajaran yaitu penelitian yang dilakukan oleh (Ummah \& Budiyono, 2018) tentang penerapan strategi everyone is a teacher here untuk meningkatkan hasil belajar matematika kelas IV; (Febrianti \& Suprayitno, 2017) tentang penerapan strategi pembelajaran everyone is a teacher here untuk meningkatkan keterampilan pemecahan masalah sosial siswa pada mata pelajaran IPS kelas IV SDN Jatilangkung Mojokerto. (Zuliani \& Nasir, 2017) tentang Penerapan Model Pembelajaran Everyone Is A Teacher Here (ETH) untuk Meningkatkan Aktivitas dan Hasil Belajar Kimia Koloid Siswa Kelas XI IA di SMA Negeri 5 Banda Aceh; (Firdaus, 2018) tentang penerapan model pembelajaran Everyone Is A Teacher Here (ETH) untuk meningkatkan kepercayaan diri siswa. Namun dari beberapa penelitian tersebut hanya mengukur peningkatan hasil belajar matematika siswa sedangkan penelitian ini selain mengukur peningkatan hasil belajar juga mengukur seberapa besar pengaruh model terhadap hasil belajar.

Berdasarkan observasi yang dilakukan pada SMA Negeri 1 Latambaga dan mewawancarai salah satu guru mata pelajaran matematika kelas XI yaitu Ibu Irmayana Nyompa S.Pd, diketahui bahwa selama ini pembelajaran matematika walaupun sudah menggunakan penerapan pembelajaran saintifik kurikulum K-13, namun hanya siswa tertentu yang ikut aktif dalam proses pembelajaran, selanjutnya guru lebih banyak menjelaskan sehingga pembelajaran lebih terpusat pada guru, hal tersebut membuat siswa sukar memahami konsep-konsep matematika, selain itu diperoleh informasi bahwa rata-rata hasil belajar matematika siswa khususnya kelas XI MIA berdasarkan ulangan harian yaitu 64,14 dengan persetase ketuntasan $20 \%$ untuk kelas MIA1 dan 69,52 untuk kelas MIA2 dengan persentase ketuntasan 40,47\%, masih di bawah nilai Kriteria Ketuntasan Minimum (KKM) yang diterapkan oleh sekolah yakni 75 dan 
persentase ketuntasan masih dalam kategori rendah untuk kelas MIA1 dan kelas MIA2. Selain itu kendala terbesar kedua ada pada gurunya, dimana guru menerapkan pembelajaran yang tidak bervariasi dan kurang perhatian dari siswa, akibatnya siswa cenderung pasif dan hanya mendengarkan apa yang disampaikan oleh gurunya, dua kendala tersebut jika tidak di atasi maka akan berdampak pada hasil belajar siswa.

Berdasarkan permasalahan yang dikemukakan di atas maka perlu adanya mencari sebuah strategi pembelajaran yang tepat agar bisa meningkatkan aktivitas dan hasil belajar siswa. Adapun salah satu strategi pembelajaran yang dianggap dapat meningkatkan aktivitas dan hasil belajar siswa pada mata pelajaran matematika adalah strategi pembelajaran aktif. Uno (2012); Asiah (2017); Maonde et al.; (2015) bahwa strategi pembelajaran aktif adalah salah satu strategi yang digunakan untuk mengoptimalkan proses pembelajaran, yang senantiasa memposisikan guru sebagai orang yang menciptakan suasana belajar yang kondusif

atau sebagai fasilitator dalam belajar, sementara peserta didik harus aktif, inovatif dan lingkungan dimanfaatkan sebagai sumber belajar yang kreatif, efektif, dan menarik. Silberman (2016); Ummah \& Budiyono (2018) menjelaskan bahwa ketika kegiatan belajar sifatnya pasif, siswa mengikuti pelajara tanpa rasa keingintahuan, tanpa mengajukan pertanyaan, dan tanpa minat terhadap hasilnya. Ketika kegiatan belajar bersifat aktif, siswa akan mengupayakan sesuatu, menginginkan jawaban atas sebuah pertanyaan, dan membutuhkan informasi untuk memecahkan masalah. Dalam pembelajaran aktif terdapat banyak tipe yang dapat digunakan dalam proses belajar mengajar di kelas, salah satunya yaitu strategi pembelajaran Everyone is a Teacher here (setiap orang adalah guru disini). Silberman (2016); Ummah \& Budiyono, (2018) Menyatakan bahwa strategi pembelajaran aktif tipe Everyone is a Teacher Here merupakan strategi pembelajaran yang memungkinkan peserta didik lebih aktif dan dapat menjadi guru atau pembimbing bagi temannya. Strategi ini memberikan kesempatan bagi setiap siswa untuk bertindak sebagai guru bagi siswa lain. Strategi pembelajaran Everyone is a Teacher Here ini juga dapat digunakan untuk memastikan keterlibatan seluruh siswa dalam proses pembelajaran.

Adapun tujuan dari penelitian ini adalah untuk mengetahui hasil belajar matematika dan pengaruh strategi pembelajaran Everyone is a Teacher Here terhadap hasil belajar matematika siswa kelas XI MIA SMA Negeri 1 Latambaga.

\section{METODE PENELITIAN}

Jenis penelitian ini adalah penelitian eksperimen. Penelitian ini termasuk dalam bentuk Quasi Experimental (eksperimen semu). Penelitian ini menggunakan dua kelas yakni, kelas eksperimen dan kelas kontrol. Pembelajaran Everyone is a Teacher Here yang diberikan kepada siswa kelas eksperimen dan pembelajaran konvensional yang diberikan kepada siswa kelas kontrol. Penelitian ini dilaksanakan di SMA Negeri 1 Latambaga Kelas XI MIA semester ganjil pada tanggal 26 Agustus hingga 14 September Tahun ajaran 2019/2020. Adapun populasi dalam penelitian ini adalah seluruh siswa kelas XI MIA yang terbagi kedalam dua kelas yaitu MIA 1 sebanyak 35 siswa dan 
$\mathrm{MIA}_{2}$ sebanyak 42 orang. Pengambilan sampel dalam penelitian ini menggunakan teknik purposive sampling.

Dalam penelitian ini dipilih kelas XI MIA ${ }_{1}$ sebagai kelas eksperimen dan kelas XI MIA 2 sebagai kelas kontrol dengan pertimbangan nilai rata-rata kelas XI MIA $_{1}$ dengan persentase ketuntasan 20\% lebih kecil dari pada nilai rata-rata kelas XI $\mathrm{MIA}_{2}$ dengan persentase ketuntasan 40,47\% berdasarkan nilai yang diperoleh dari nilai ulangan harian siswa. Desain yang digunakan dalam penelitian ini adalah desain penelitian eksperimen dengan rancangan Nonequivalent Control Group Design yang disajikan pada Tabel 1. (Sugiyono, 2016: 79)

Tabel 1. Desain penelitian.

\begin{tabular}{cccc}
\hline $\mathrm{KE}$ & $\mathrm{O}_{1}$ & $\mathrm{X}$ & $\mathrm{O}_{2}$ \\
$\mathrm{KK}$ & $\mathrm{O}_{3}$ & - & $\mathrm{O}_{4}$ \\
\hline
\end{tabular}

Teknik pengumpulan data yang digunakan dalam penelitian ini adalah teknik tes dan observasi. Sedangkan Instrumen yang akan digunakan untuk mengumpulkan data adalah instrumen tes dan lembar observasi. Instrumen tes digunakan untuk mengetahui hasil belajar siswa berupa soal pree-test dan post-test berbentuk uraian (esasy) dan lembar observasi berupa lembar observasi aktivitas siswa dan lembar observasi aktivitas guru. Sebelum instrument diberikan kepada siswa sebelumnya di uji valid dan reliabilitas.

Teknik analisis dalam penelitian ini adalah teknik analisis deskriptif dan Inferensial. Teknik analisis deskriptif dimaksudkan untuk mendeskripsikan karakteristik variabel penelitian melalui skor rata-rata, standar deviasi, varians dan menghitung persentase ketuntasan hasil belajar siswa secara klasikal sedangkan analisis Inferensial untuk melihat pengaruh model pembelajaran terhadap hasil belajar siswa. Uji yang dilakukan antara lain:

1. Uji normalitas dengan IBM SPSS Statistic 25 melalui hasil Kolmogorov-Smirnov sebagai uji prasyarat untuk Independent Sample $T$-test untuk mengetahui normalitas data hasil pre-test - post-test

2. Uji homogenitas melalui dengan IBM SPSS Statistic 25 melalui Lavene Test sebagai uji prasyarat untuk Independent Sample T-test untuk mengetahui homogenitas data pretest dan post-test.

3. Uji-t yaitu independent sample t-test untuk mengetahui pengaruh strategi pembelajaran Everyone is a Teacher Here terhadap hasil belajar matematika siswa dengan melihat perbedaan nilai rata-rata hasil belajar siswa.

4. Uji Cohen's (d) untuk mengetahui seberapa besar ukuran pengaruh (effect size) model terhadap hasil belajar.

Sebelum melakukan T-test terlebih dahulu dilakukan uji normalitas data menggunakan Kolomogorof Smirnov dan uji homogenitas menggunakan Lavene Test. Jika hasil dari uji normalitas Kolmogorof Smirnov memiliki signifikansi > 0,05 maka nilai pre-test dan post-test berdistribusi normal. Namun jika signifikansi $<0,05$ maka nilai pre-test dan post-test tidak normal. Jika uji Lavene test menunjukkan signifikansi > 0,05 maka nilai pre-test dan post-test homogen. Jika signifikansi $<0,05$, maka nilai pretest dan post-test tidak homogen. Setelah memenuhi persyaratan normalitas dan homogenitas kemudian dilakukan uji T-test (Independent Sample T-test $t$ ). Jika signifikansi hasil Independent Sample T-test $<0.05$, maka 
ditolak dan menerima, Selanjutnya akan dicari seberapa besar ukuran pengaruhnya (effect size) dengan menggunakan rumus Cohen's $(d)$.

\section{HASIL DAN PEMBAHASAN}

Penelitian yang dilaksanakan mulai tanggal 26 Agustus 2019 sampai tanggal 14 September 2019 pada kelas XI MIA 1 dan XI MIA 2 di SMA Negeri 1 Latambaga, maka pada bagian hasil penelitian meliputi analisis deskriptif dan analisis inferensial. Analisis deskriptif meliputi: (1) kemampuan guru mengolah pembelajaran, (2) aktivitas siswa dalam proses pembelajaran, dan hasil belajar matematika siswa. Pembahasan tersebut akan diuraikan sebagai berikut: Nilai rata-rata persentase keaktifan guru dalam melaksanakan pembelajaran Everyone Is a Teacher Here yaitu 92,1\%. Persentase tersebut menunjukkan bahwa dalam pelaksanaan pembelajaran, guru telah mengikuti langkah-langkah pembelajaran Everyone Is a Teacher Here sesuai dengan sintaknya. Sementara pada pembelajara konvensional rata-rata persentase keaktifan guru dalam melaksanakan pembelajaran yaitu $89.99 \%$. Hal ini menunjukkan bahwa guru sudah mampu melaksanakan kedua proses pembelajaran tersebut sesuai dengan penerapannya saat proses pembelajaran berlangsung. Rata-rata persentase untuk aktivitas siswa dalam proses pembelajaran Everyone Is a Teacher Here yaitu 75,79\%. Sementara pada pembelajara konvensional rata-rata persentase keaktifan siswa dalam proses pembelajaran yaitu $67,86 \%$. Hal ini menunjukkan bahwa aktivitas siswa dalam proses pembelajaran baik pada kelas eksperimen maupun kelas kontrol termasuk dalam kategori aktif.
Secara deskriptif hasil belajar siswa melalui perhitungan rata-rata skor pre-test kelas kontrol dan eksperimen dapat dilihat pada Tabel 2 dan 3 .

Tabel 2. Hasil analisis deskriptif pretest post-test kelas eksperimen.

\begin{tabular}{cccc}
\hline \multirow{2}{*}{ No } & \multirow{2}{*}{ Deskriptif } & \multicolumn{2}{c}{ Eksperimen } \\
\cline { 3 - 4 } & & Pre-test & Post-test \\
\hline 1 & Mean & 31.029 & 74.943 \\
2 & Varians & 136.205 & 156.644 \\
3 & Stand. Dev & 11.671 & 12.516 \\
4 & Persentase & $0 \%$ & $68.57 \%$ \\
\hline
\end{tabular}

Tabel 3. Hasil analisis deskriptif pretest post-test kelas kontrol.

\begin{tabular}{cccc}
\hline \multirow{2}{*}{ No } & \multirow{2}{*}{ Deskriptif } & \multicolumn{2}{c}{ Kontrol } \\
\cline { 3 - 4 } & & $\begin{array}{c}\text { Pre- } \\
\text { test }\end{array}$ & Post-test \\
\hline 1 & Mean & 30.31 & 50.357 \\
2 & Varians & 222.658 & 262.821 \\
3 & Stand. Dev & 14.921 & 16.212 \\
4 & Persentase & $2.86 \%$ & $9.52 \%$ \\
\hline
\end{tabular}

Selanjutnya perbedaan rata-rata hasil belajar siswa pada kelas eksperimen dan kelas kontrol digambarkan dalam bentuk Gambar 1 . Berdasarkan Gambar 1 dapat diketahui bahwa pada kelas eksperimen rata-rata skor pree-test sebesar 31,03 kemudian setelah dilakukan post-test diperoleh rata-rata skor post-test sebesar 74,94, artinya terdapat peningkatan hasil belajar secara deskriptif sebesar 43,91. Pada kelas kontrol rata-rata skor pree-test sebesar 30,31 kemudian setelah dilakukan post- test diperoleh rata-rata skor post-test sebesar 50,36, artinya terdapat peningkatan hasil belajar sebesar 20,05. 
DOI: https://doi.org/10.24127/ajpm.v9i2.2764

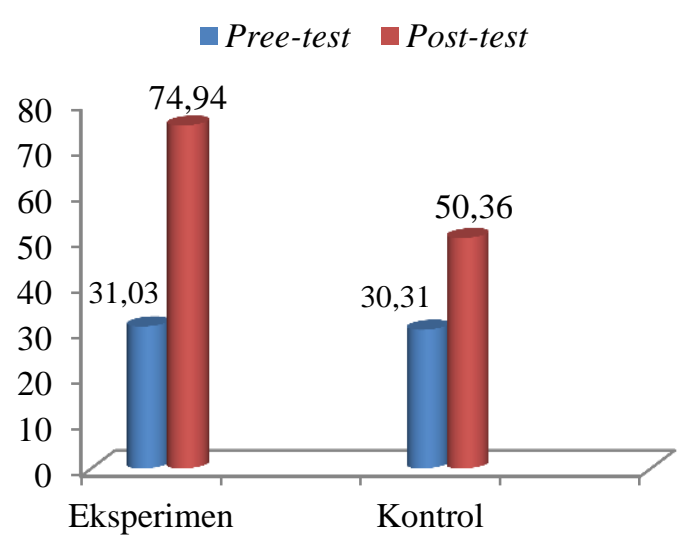

Gambar 1. Rata-rata hasil belajar.

Sebelum di analisis secara inferensial untuk melihat pengaruh model pembelajaran terhadap hasil belajar, terlebih dahulu dilakukan uji pra syarat analisis yaitu uji normalitas dan uji homogenitas. Adapun hasil uji normalitas dapat dilihat pada Tabel 4 dan Tabel 5.

Tabel 4. Uji normalitas pre-test.

\begin{tabular}{cccc}
\hline \multirow{2}{*}{ No } & \multirow{2}{*}{ ji } & \multicolumn{2}{c}{ Pre-test } \\
\cline { 3 - 4 } & Prasyarat & $D_{\text {hitung }}$ & $D_{\text {tabel }}$ \\
\hline 1 & Eksperimen & 0.2097 & 0.224 \\
2 & Kontrol & 0.1876 & 0.198 \\
\hline
\end{tabular}

Tabel 5. Uji normalitas post-test.

\begin{tabular}{cccc}
\hline \multirow{2}{*}{ No } & \multirow{2}{*}{$\mathbf{j i}$} & \multicolumn{2}{c}{ Post-test } \\
\cline { 3 - 4 } & Prasyarat & $D_{\text {hitung }}$ & $D_{\text {tabel }}$ \\
\hline 1 & Eksperimen & 0.1875 & 0.224 \\
2 & Kontrol & 0.1298 & 0.198 \\
\hline
\end{tabular}

Jika $D_{\text {hitung }}>D_{\text {tabel }}$ maka data tidak berdistribusi normal sedangkan jika $D_{\text {hitung }}<D_{\text {tabel }}$ maka berdistribusi normal. Dari Tabel 4 dan Tabel 5 bahwa hasil uji normalitas dengan Kolmogorov Smirnov di atas kedua kelas berdistribusi normal yang

$$
\begin{aligned}
& \text { dapat ditunjukkan dengan } \\
& D_{\text {hitung }}<D_{\text {tabel }} \text {. }
\end{aligned}
$$

Analisis uji homogenitas dengan menggunakan statistik uji $F$ dapat dilihat pada Tabel 6 .

Tabel 6. Uji homogenitas.

\begin{tabular}{cccc}
\hline \multirow{2}{*}{ No } & \multirow{2}{\text{Uji}}{} & \multicolumn{2}{c}{ Homogenitas } \\
\cline { 3 - 4 } & Prasyarat & $\boldsymbol{F}_{\text {hitung }}$ & $\boldsymbol{F}_{\text {tabel }}$ \\
\hline 1 & Pre-test & 1.635 & 1.741 \\
2 & Post-test & 1.678 & 1.741 \\
\hline
\end{tabular}

Dari Tabel 6 diketahui bahwa hasil uji homogenitas dengan Lavene test menunjukan bahwa $\mathrm{F}_{\text {hitung }}<\mathrm{F}_{\text {tabel }}$ maka kedua kelas homogen.

Karena telah memenuhi syarat yaitu berdistribusi normal dan kedua kelas homogen selanjutnya dilakukan uji hipotesis dengan menggunakan Independent T-test (Polled Varians) untuk melihat pengaruh ositif dan signifikan strategi Everyone is a Teacher Here (ETH) terhadap hasil belajar siswa. Adapun hasil uji Independent $T$-test Diperoleh $\mathrm{t}_{\text {hitung }}=$ $(5,360)$ dan $t_{\text {tabel }}$ dengan derajat kebebasan yaitu $d k=n_{1}+n_{2}-2$ $=35+42-2=75$ yaitu $(1,992)$. Karena nilai $t_{\text {hitung }}(5,360)>t_{\text {tabel }}(1,992)$ dengan demikian maka $\mathrm{H}_{0}$ ditolak, dan secara otomatis $\mathrm{H}_{1}$ diterima dengan kata lain terdapat pengaruh positif dan signifikan strategi pembelajaran Everyone is a Teacher Here terhadap hasil belajar matematika siswa kelas XI MIA SMA Negeri 1 Latambaga, dengan kata lain nilai rata-rata hasil belajar kelompok siswa yang diajar menggunakan strategi pembelajaran Everyone is a Teacher Here lebih tinggi dari pada nilai ratarata hasil belajar siswa yang diajar dengan menggunakan pembelajaran konvensional. Kemudian untuk 
mengukur seberapa besar pengaruh yang ditimbulkan akibat penggunaan strategi pembelajaran Everyone is a Teacher Here maka dilakukan perhitungan effect size menggunakan rumus Cohens $(d)$. Menurut (Nugroho et al., 2020) bahwa effect size merupakan ukuran yang pasti. Effect size didefinisikan sebagai hasil pengurangan mean kelompok eksperimen dengan mean kelompok kontrol pada veriabel kriteria dibagi dengan simpangan baku dari kelompok. Berdasarkan hasil perhitungan diperoleh effect size sebesar 1,23 yang termasuk dalam kategori efek sangat besar. Hasil penelitian ini sejalan dengan penelitian yang dilakukan oleh (Jafar et al., 2018); (Fitriani, 2018); (Aryaningrum, 2015); (Ningsih \& Gustimalasari, 2018) yang menyatakan bahwa strategi pembelajaran Everyone is a Teacher Here berpengaruh positif dan signifikan terhadap hasil belajar.

Berdasarkan deskripsi dan analisis data yang telah diperoleh, dapat dijelaskan pada kelas XI MIA ${ }_{1}$ sebagai kelas eksperimen dan kelas XI MIA 2 sebagai kelas kontrol telah melakukan pretest dengan menjawab 4 butir soal Essay. Pretest dilakukan untuk mengetahui skor awal siswa sebelum diberi perlakuan. Melalui hasil pretest di kelas eksperimen diperoleh rata-rata 31,03 dengan kategori jelek dan kelas kontrol diperoleh rata-rata 30,31 dengan kategori jelek.

Sedangkan melalui hasil postest, diketahui bahwa hasil belajar kelas eksperimen setelah diberi perlakuan dengan strategy everyone is a teacher here lebih tinggi daripada kelas kontrol yang menggunakan metode konvensional. Hal ini dilihat dari nilai rata-rata yang diperoleh kelas eksperimen adalah 74.94 dengan kategori cukup dan kelas kontrol 50.36 kategori jelek. Berdasarkan hasil tersebut dapat dilihat bahwa kelas eksperimen jumlah siswa yang mampu mencapai nilai kriteria ketuntasan minimal (KKM) sebanyak 24 siswa dan yang belum mencapai kriteria ketuntasan minimal (KKM) sebanyak 11 siswa. Sedangkan pada kelas kontrol jumlah siswa yang mampu mencapai nilai kiteria ketuntasan minimal (KKM) sebanyak 4 siswa dengan dan yang belum mencapai KKM sebanyak 38 siswa.

Sedangkan untuk aktivitas siswa menunjukkan bahwa aktivitas siswa dalam proses pembelajaran Everyone Is a Teacher Here yaitu $75,79 \%$ dan termasuk dalam kategori aktif. Sementara pada pembelajaran konvensional rata-rata persentase keaktifan siswa dalam melaksanakan pembelajaran yaitu $67,86 \%$ dan juga termasuk dalam kategori aktif. Hal ini menunjukkan bahwa siswa aktif saat proses pembelajaran berlangsung

Peningkatan hasil belajar dan keaktifan siswa melalui strategi everyone is a teacher here ditunjukkan dengan siswa antusias mengikuti pembelajaran seperti siswa lebih fokus mengikuti kegiatan pembelajaran, siswa tidak lagi melakukan aktivitas diluar pembelajaran, siswa semangat mencari jawaban dan berani menjawab pertanyaan tanpa dipanggil terlebih dahulu namanya kemudian menjelaskan kepada teman-temanya didepan kelas.

Berbeda dengan pembelajaran di kelas kontrol yang menggunakan metode konvensional yaitu ceramah, meskipun terjadi peningkatan dalam hasil belajar dan keaktifan, namun masih banyak siswa yang enggan bertanya dan memberikan pendapat, walaupun ada beberapa siswa yang bertanya jika kurang mengerti dan siswa yang berani menjawab pertanyaan, 
siswa yang pasif dalam pembelajaran ada yang tidur dan ngobrol dengan teman sebangku atau teman dibelakangnya. Sehingga strategi everyone is a teacher here diterapkan pada kelas kontrol lebih baik dibandingkan dengan metode ceramah.

Pada metode pembelajaran everyone is a teacher here guru berperan sebagai fasilitator dan evaluator, hal ini sejalan yang disampaikan oleh Huda et al. (2015); Suparta, dkk (2015); Fidiyanti (2017) bahwa guru sebagai manager dan fasilitator pembelajaran. Guru sebagai fasilitator ditunjukkan dengan menciptakan suasana belajar yang menyenangkan namun tetap kondusif dan menghindari pemelajaran yang didominasi pada guru, sehingga kegitan belajar mengajar berlangsung secara efektif dan optimal. Sedangkan sebagai evaluator, guru menilai jawaban dari siswa selama proses dan setelah proses pembelajaran baik jawaban siswa pelaksanaan metode everyone is a teacher here serta pada saat pengerjaan soal pretest dan postest. Sedangkan keaktifan siswa di nilai oleh siswa itu sendiri dan observer yaitu guru mata pelajaran matematika.

Kelebihan strategi everyone is a teacher here yaitu melatih siswa untuk dapat berperan sebagai guru di hadapan temannya, meningkatkan kemampuan siswa dalam mengemuka-kan pendapat, meningkatkan kemampuan siswa dalam menganalisis masalah, mengembangkan kemampuan berfikir sendiri dalam memecahkan masalah yang dihadapi sehingga tumbuh konsep diri yang positif, meningkatkan keterampilan siswa dalam membuat simpulan, membina perasaan tanggungjawab mengenai pendapat, kesimpulan atau keputusan yang telah dan akan diambil.

\section{KESIMPULAN DAN SARAN}

Berdasarkan hasil penelitian dan pembahasan dapat disimpulkan bahwa hasil belajar dan keaktifan siswa dengan strategi pembelajaran everyone is a teacher here lebih tinggi daripada menggunakan model pembelajaran konvesional, selain itu strategi pembelajaran everyone is a teacher here mempunyai pengaruh yang positif dan signifikan terhadap hasil belajar matematika siswa kelas XI MIA SMA Negeri 1 Latambaga

Pada pembelajaran matematika, strategi pembelajaran Everyone is a Teacher Here dapat digunakan sebagai alternatif pembelajaran untuk meningkatkan hasil belajar matematika. Bagi peneliti lain yang hendak mengembangkan penelitian ini, dapat melakukannya pada materi lain dalam upaya meningkatkan hasil belajar matematika siswa.

\section{DAFTAR PUSTAKA}

Aryaningrum, K. (2015). Pengaruh Strategi Pembelajaran Everyone Is a Teacher Here Terhadap Hasil Belajar Siswa Pada Mata Pelajaran Ips Terpadu (Geografi) Di Kelas Viii Smp Negeri 1 Belitang Iii Oku Timur. Jurnal Ilmiah Civis, 5(2), 798-807.

Asiah, N. (2017). Analisis kemampuan praktik strategi pembelajaran aktif ( active learning ) mahasiswa PGMI Fakultas Tarbiyah dan Keguruan IAIN Raden Intan Lampung. Jurnal Pendidikan Dan Pembelajaran Dasar, 4(1), 20-33.

Febrianti, P., \& Suprayitno. (2017). Penerapan Strategi Pembelajaran Everyone is a Teacher Here untuk Meningkatkan Keterampilan Pemecahan Masalah Sosial Siswa pada Mata Pelajaran IPS Kelas IV SDN Jatilangkung Mojokerto. 
DOI: https://doi.org/10.24127/ajpm.v9i2.2764

Jurnal Penelitian Pendidikan Guru Sekolah Dasar(JPGSD), 5(3), 684-693.

Fidiyanti, H. H. N. (2017). Effect Of Implementation Of Cooperative Learning Model Make A Match Technique On Student Learning Motivation In Social Science Learning. International Journal Pedagogy of Social Studies, 2(1), 104.

https://doi.org/10.17509/ijposs.v2i 1.8667

Firdaus, A. R. (2018). Application Of Everyone is a Teacher Here Learning Model to Improve Self Confidence Students. Journal of Elementary Education, 2(2), 8795.

https://doi.org/https://doi.org/10.22 460/pej.v2i2.1007

Fitriani. (2018). Pengaruh Metode Pembelajaran Everyone Is Teacher Here Dengan Media Handout Terhadap Keaktifan Dan Hasil Belajar Siswa Kelas XI IPS SMAN 1 Perhentian Raja. Jurnal Pendidikan Ekonomi Akuntansi FKIP UIR, 6(1), 44-52.

Huda, M., Kartanegara, M., Gamal, \& Zakaria, N. (2015). The Effect of Learning Strategy of Reading Aloud on Students' Achievement in the Subject of Islamic Studies at Secondary School in Semarang, Indonesia. International Journal of Education and Research, 3(2), 577-588.

Jafar, R. A., Side, S., \& Maryono. (2018). Pengaruh Metode Everyone is A Teacher Here terhadap Motivasi dan Hasil Belajar Siswa Kelas X SMA Negeri 18 Makassar pada Materi Pokok Ikatan Kimia The Effect of Everyone is A Teacher Here Method towards Motivation and
Student 's Achievement 10 th Class o. Jurnal Chemical, 19(1), 36-45.

Maonde, F., Bey, A., Anggo, M., Rahim, U., \& Tiya, K. (2015). The Discrepancy of Students' Mathematic Achievement through Cooperative Learning Model, and the ability in mastering Languages and Science. International Journal of Education and Research, 3(1), 141-158.

Ningsih, S. Y., \& Gustimalasari. (2018). Penggunaan Strategi Pembelajaran Aktif Everyone is a teacher Here (ETH) Terhadap Kemampuan Pemahaman Konsep Matematika Ssiwa Kelas VII. Journal of Mathematics Education and Science(MES), 4(1), 95-100.

Nugroho, A. A., Dwijayanti, I., \& Atmoko, P. Y. (2020). Pengaruh Model Pembelajaran Berbasis Penemuan dan lingkungan Terhadap Kemampuan Pemecahan Masalah Matematika Melalui Meta Analisis. Jurnal Program Studi Pendidikan Matematika (Aksioma), 9(1), 147-157.

Sucidamayanti, N. P. W. (2017). Penerapan Model Pembelajaran Kooperatif Tipe Numbered Heads Together (Nht) Untuk Meningkatkan Hasil Belajar Ips. International Journal of Education Action Research, 1(3), 115-124. https://doi.org/10.23887/jear.v1i3.1 2683

Tambunan, H. (2018). Impact of Heuristic Strategy on Students' Mathematics Ability in High Order Thinking. International Electronic Journal of Mathematics Education, 13(3), 321-328. https://doi.org/10.12973/iejme/392 8 
DOI: https://doi.org/10.24127/ajpm.v9i2.2764

Ummah, N. A., \& Budiyono. (2018). Penarapan Strategi Everyone is a Teacher Here Untuk MEningkatkan Hasil Belajar Matematika Kelas IV. Jurnal Penelitian Guru Sekolah Dasar(JPGSD), 06(03), 322-331.

Zuliani, P., \& Nasir, M. (2017). Penerapan Model Pembelajaran Everyone Is A Teacher Here ( ETH ) untuk Meningkatkan Aktivitas dan Hasil Belajar Kimia Koloid Siswa Kelas XI IA di SMA Negeri 5 Banda Aceh Abstrak Pendahuluan. Jurnal Ilmiah Mahasiswa Pendidikan Kimia(JIMPK), 2(1), 65-72. 